\title{
CREATING POETRY IN TIME PERSPECTIVE
}

\author{
Olga D. VOLCHEK
}

International Science and Research Institute of Cosmoplanetary Anthropoecology named after the academician V.P. Kaznacheev

\begin{abstract}
The author discusses the results of a study of multiyear variations in the occurrence of letters in 12,925 pieces of poetry composed by 317 Russian poets in 1796-2012 in correlation with geocosmic weather and of seasonal variations in the occurrence of letters in 2,551 poems by 132 male poets and 30 female poets. The conclusion is that there are multiyear and seasonal fluctuations of the occurrence of letters, which, for virtually all 33 letters, are synergetic with variations in the main indices of geocosmic weather. Temperature, Earth's rotation rate, precipitation and solar activity indices appear to be the most influential ones, with $23,17,17$ and 11 correlations, respectively, at $p \leq 0.05-0.001$. Seasonal variations in parameters of poetry created by men and by women are significantly different, which reflects gender differences in natural adjustment.
\end{abstract}

Keywords: adjustment; articulation; geocosmic weather; poetry; psychophysiological condition; psycholinguistics; ecopsychology

\section{INTRODUCTION}

Abrupt changes in climate and continuously rising frequency of natural disasters actualize the problem of the person's adjustment to changes in their environment. Solving this problem can be facilitated by the combined application of the latest findings of social and medical-biological sciences, particularly in the fields of culturology, ecopsychology, social anthropology, psycholinguistics and logopedics.

Rhythmic and cyclic patterns are considered a distinctive feature of adjustment mechanisms. There are two types of adjustment: genotypic and pheno- 
typic. Social adjustment is one of the finest manifestations of adjustment. From the earliest stages of historical process, the major means of social adjustment were culture and religion. Culture is "the second nature, the second human habitat..." [11, p. 25-26]. Authentic pieces of culture, art and music provide necessary mind mode and high spirit helping people withstand tough historical times. This is true for poetry, as well.

Poems help personal development and can heal a person, which is described in the monograph Mental Health And Poetry by O. Danilenko. As the author says, poetry brings three gifts to people: the ability to take one beyond empirical reality into the world of spiritual gists and landmarks, to give knowledge of somebody else's spiritual life experience and to provoke a certain mood [3, p.44]. K.I. Chukovskiy said: "...poetry gives us the most profound rest, almost impossible in this world, and immediately renews our bodily tissue..." [2, p. 252]. But poetry is not just a cultural phenomenon, it is a natural phenomenon, as well, as was noticed by Ya. Polonskiy, A. Block, A. Kooshner [2, p. 203; 10].

It is known that both producing and active perception of speech and musical or poetical creative processes are inseparable from the complex activity of voice muscles and one's current condition, in our case - from the poet's condition. As L. Chukovskaya stated [2, p. 338], “... a poem to a poet is a result of utmost concentration, of inner listening....”.

In the academician V.P. Kaznacheev's opinion, mental state often serves as a measure and a highly sensitive indicator of adverse environmental impact [8, p. 161]. Frequency of using certain speech sounds can serve as such an indicator of interaction between the human body and habitat, due to multicomponent semantics of speech sounds and their influence on brain biorhythms [27, 16]. A word's acoustic image and even a letter-sound's image "triggers a physiological process leading to changes in the rhythm of brain waves, changes of attributes and their combinations and changes in color associations" [16, p. 431].

Previously we detected a correlation of speech perception and composing lyrics with a set of environmental conditions, where, for the period of 19351989, the main factors for a majority of letters were Earth's rotation rate and interplanetary magnetic field $[24,25,26]$. The object of this work was studying daily, seasonal and multiyear variations in poetical writings by men and women in correlation with geocosmic weather. 


\section{MATERIALS AND METHODS}

Since the longer studied period the clearer manifestation of long-term variations, poems by Russian authors written in the late $18^{\text {th }}-$ the early $21^{\text {st }}$ century were analized. Philologists' works allowed taking frequency of letter-sounds for a basic research unit; the choice was supported with their high availability for studying [16, 27].

The grounds for the study were the collections of selected poems and the collected works of well-known poets printed on paper or digitalized at the websites Russkaya Poeziya http://rupoem.ru/, Biblioteka Russkoy Poezii http://libverse.ru/, Stihi Velikih Russkih Poetov http://strofa.su/vse-poety/, Sovremennaya Poeziya http://stihi.ru/, as well as poems from the magazine Novyi Mir for the years 1993-2014 http://magazines..ru/novyi_mi/. The data was being collected during 2015-2016.

Only poems with a strict date of composition were selected for the study. Short poems were preferred, since they are normally composed spontaneously which means they reflect the impact of geocosmic weather onto the poet more fully. In all possible cases we used an equal ratio of poems by different authors. It should be mentioned that the letter $\ddot{E}$ [yo] was replaced with $\mathrm{E}$ [ye] in poetic texts printed in certain years due to the printing practice of that time and this is why the results for letters $\mathrm{E}$ and $\mathrm{E}$ are not quite relevant.

The software Blagozvuchie developed by K.D. Mikheev was employed for calculating the frequencies of occurrence of each letter. The data obtained were juxtaposed with the average annual values of weather indices. Since data on most weather parameters is not available for the $18^{\text {th }}$ and the $19^{\text {th }}$ centuries, we only used the following indices for those periods: solar activity (Wolf sunspot number) W, air temperature $t^{\circ}$, the amount of precipitation in St. Petersburg, Russia, $R$ and Earth's rotation rate (deviation from the standard of 86,400 sec) ERR. When analyzing the data for the $20^{\text {th }}$ and $21^{\text {st }}$ centuries, some other geocosmic indices were used, as well.

Engaging the index ERR is justified by the importance of this factor: the changes of its values precede changes in solar activity and further in air temperature on Earth. It was shown that tidal variations in Earth rotation correspond to the changes in meteorological parameters, which allowed developing and patenting a weather forecasting method. The analysis of changes in weather in Moscow and Vladivostok showed that while the current values of weather parameters differ from the patterns of their variation there were in most cases similar $[19,20]$. Therefore using weather data from the only location, St Petersburg, is appropriate for our study. 
Besides frequencies of letter occurrence, we also calculated the significance of gaps between the highest and the lowest occurrence of each letter for various periods and registered the quantity of poems and the total number of letters for certain periods. Mathematical analysis of the data was performed with Statistica 7.0 software, engaging the Fisher criterion $\varphi^{*}$ and correlation analysis. The obtained data is presented in the tables and figures.

\section{RESULTS AND DISCUSSION}

By the moment we have collected and studied the data for 12,925 poems by 317 authors, including 47 female poets, composed in 1795-2014. The dataset for studying multiyear variations included the poems by emigrated authors and the poems by several modern authors written abroad, mostly in Europe. The number of poets for a certain year varied from 4 (in 1798) to 37 (in 1957). From this dataset we selected 2,551 poems dated with a year and a month.

For the studied period, significant and relevant variations in the occurrence of each of the 33 letters of the Russian alphabet were detected. Examples are presented in Table 1.

Table 1. Variations in letter occurrence, $\%$, in poems from 1796-2011.

\begin{tabular}{cccccc}
\hline Letter & Max. \% & Year & Min. \% & Year & $\varphi . \mathbf{p}<0.001$ \\
\hline A [a] & 8.206 & 1926 & 6.197 & $\mathbf{1 8 0 1}$ & 9.2 \\
\hline В [b] & 5.365 & $\mathbf{1 8 0 1}$ & 3.946 & 1886 & 6.72 \\
\hline И [i] & 6.812 & 1984 & 5.772 & 1876 & 4.84 \\
\hline H [n] & 7.431 & 1896 & 5.704 & 1810 & 6.08 \\
\hline О [o] & 10.874 & 1871 & 8.423 & 1806 & 8.37 \\
\hline У [u] & 3.268 & 1977 & 2.304 & 1872 & 5.49 \\
\hline Ц [tz] & 0.721 & 1804 & 0.285 & 1972 & 7.47 \\
\hline Ы [y] & 2.868 & 1900 & 1.926 & 1968 & 6.87 \\
\hline Э [æ] & 0.283 & 1954 & 0.019 & $\mathbf{1 8 0 1}$ & 9.96 \\
\hline
\end{tabular}

Correlation analysis was performed for a few periods within the $19^{\text {th }}$ and the $20^{\text {th }}$ centuries, as well as for the whole studied period. Multiple stable correlations were detected at $p \leq 0.05-0.001$. The number of detected correlations and the hierarchy of leading geocosmic weather indices varied, which was determined by the combination of environmental conditions. For instance, the number 
of correlations between the ERRD index and the occurrence of certain letters equaled 12 for the period of 1801-1900 and 17 for the period of 1901-2000 at $p \leq 0.05-0.001$ and 17 for the period of 1801-2001, with 8 correlations at $p<0.001$.

For the lyrics and poems written in 1935-1989, correlation pleiades patterns were different. This might be caused by primary differences between poetical texts and lyrics and by requirements for lyrics: simply designed phrases, easy to pronounce words and, most importantly, figurative fusion with music [9].

The results of the correlation analysis for the period of 1801-2000 turned out to be of great interest (see Table 2 and Figure 1). The temperature index bears the heaviest load here, with 23 correlations out of 33 possible ones. The revealed association confirms the ideas of global warming. It is worth mentioning that warming is followed with rising social aggression [12].

Table 2. Major indices correlations for 1801-2000.

\begin{tabular}{|c|c|c|c|c|c|c|c|c|c|}
\hline Letter & $\begin{array}{c}\text { Tem- } \\
\text { pera- } \\
\text { ture }\end{array}$ & ERR & $\begin{array}{l}\text { Precip- } \\
\text { itation }\end{array}$ & W & Letter & $\begin{array}{c}\text { Tem- } \\
\text { pera- } \\
\text { ture }\end{array}$ & ERR & $\begin{array}{l}\text { Pre- } \\
\text { cipita- } \\
\text { tion }\end{array}$ & w \\
\hline $\mathrm{A}[\mathrm{a}]$ & $+* * *$ & $-* * *$ & + & $+* *$ & $\Pi[p]$ & $+* *$ & & $t^{* * * *}$ & \\
\hline $5[b]$ & $-* * *$ & $+* * *$ & & & $P[r]$ & & & & + \\
\hline$B[v]$ & - & $+* * *$ & & & $\mathrm{C}[\mathrm{s}]$ & $-* * *$ & $+* * *$ & & \\
\hline$\Gamma[\mathrm{g}]$ & & $+* *$ & & & $\mathrm{~T}[\mathrm{t}]$ & $+* * *$ & & + & \\
\hline Д [d] & $-* *$ & $+* * *$ & & & $\mathrm{y}[\mathrm{u}]$ & & & $t^{* *}$ & - \\
\hline E [ye] & - & & $-* *$ & & $\Phi[f]$ & + & - & + & $-* *$ \\
\hline Ë [yo] & $+* * *$ & & $+^{* *}$ & $+* *$ & $\mathrm{X}[\mathrm{h}]$ & - & & & \\
\hline $\%$ [zh] & & + & & & Ц [tz] & $-* * *$ & + & $-* *$ & \\
\hline $3[\mathrm{z}]$ & & $-* *$ & & & $4[\mathrm{ch}]$ & $+* * *$ & $-* *$ & & \\
\hline И [i] & & & & $-* * *$ & Ш [sh] & $+* *$ & & + & \\
\hline$\breve{и}[j]$ & $-* * *$ & $+* * *$ & $-* * *$ & $+* *$ & Щ [sch] & & $-* *$ & & - \\
\hline $\mathrm{K}[\mathrm{k}]$ & $+* * *$ & $-* * *$ & $+^{* *}$ & & $\mathrm{~b}$ [hard sign] & & + & & \\
\hline ת [l] & - & & & $-* *$ & bl [y] & $-* *$ & & $-{ }^{* * * *}$ & $+* * *$ \\
\hline$M[\mathrm{~m}]$ & $-* * *$ & & $-^{* *}$ & - & $\mathrm{b}$ [soft sign] & & + & & \\
\hline $\mathrm{H}[\mathrm{n}]$ & $-* *$ & & $-^{* *}$ & $+* * *$ & Э [æ] & $+* * *$ & -*** & + & \\
\hline \multirow[t]{2}{*}{$\mathrm{O}[\mathrm{o}]$} & $+* *$ & & $+^{* *}$ & $+* * *$ & Ю [yu] & $-* * *$ & & - & \\
\hline & & & & & Total & 23 & 17 & 17 & 11 \\
\hline
\end{tabular}

Key: ERR - Earth rotation rate; $W$ - solar activity; ${ }^{* *}-p \leq 0,001 ;{ }^{* *}-p \leq 0,01$; the rest is $p \leq 0,05$. 

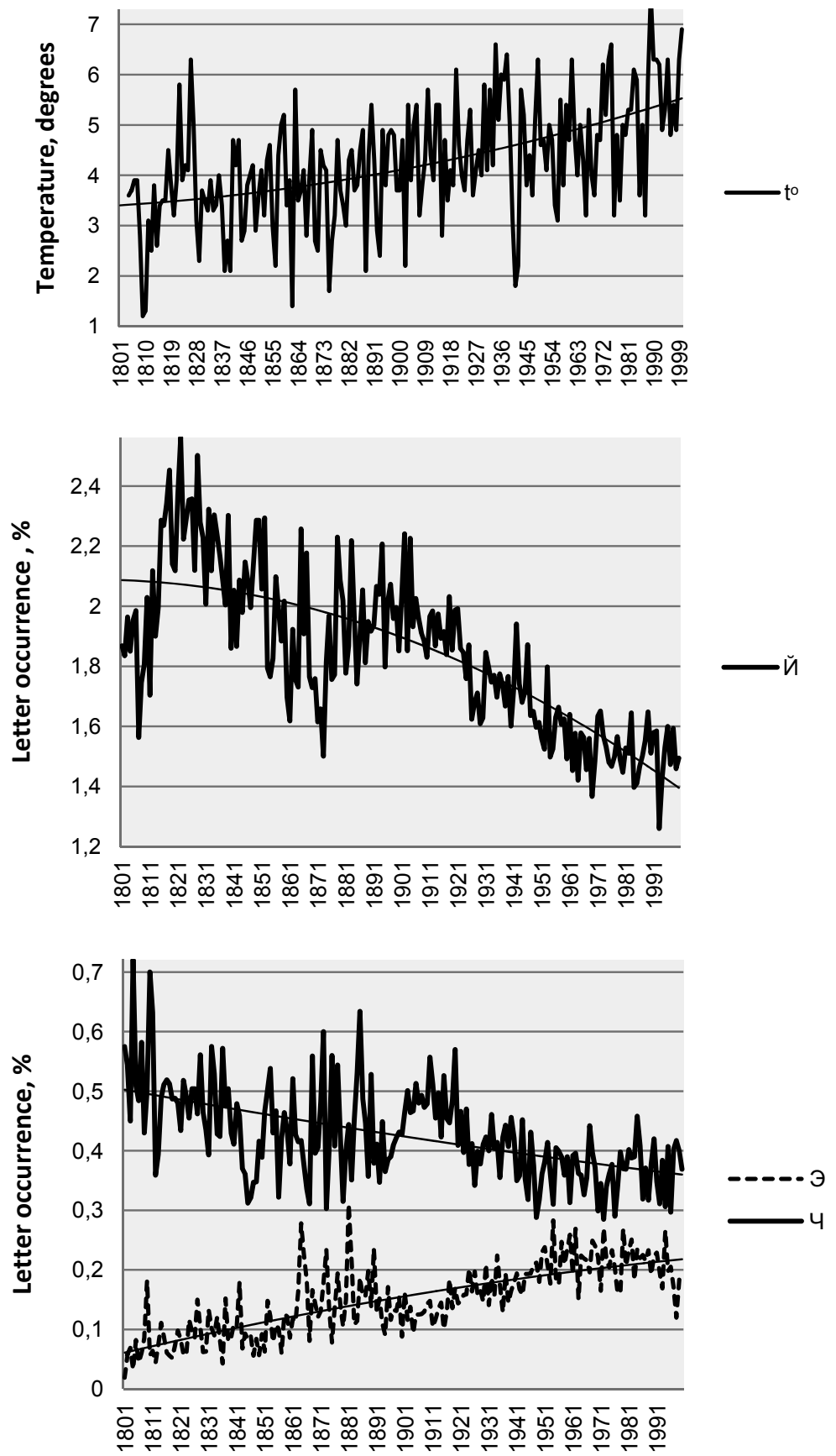

Figure 1. Correspondence of changes in yearly average temperature in St Petersburg and the frequency of letters $\breve{V}, \exists, 4$ in poems, \%. The value of correlation $r$ was, respectively, $-0.339 ; 0.384 ; 0.234 ; p<0.001$. Thin lines are for polynomial trend. 
As Table 2 shows, there are correlations for each letter of the Russian alphabet except the letter $Я[y a]$. For some letters the number of correlations at $p \leq 0.05 \div 0.001$ equals the number of studied indices. Correlation pleiades of each of the letters have specific features but there are also general trends for the period of 1801-2000. For example, rising temperature corresponds to the higher occurrence of the letters A, Ë, К, O, П, T, Ф, Ч, Ш, Э, while lowering temperature corresponds to the lower occurrence of the letters Б, В, Д, Е, Й, Л, M, H, С, Х, Ц, Ы, Ю. Rising solar activity W is associated with the higher occurrence of A, Ё, Й, Н, О, Р, Ы and lower occurrence of И, Л, М, У, Ф, Щ.

The detected multiple correlations confirm N.I. Muzalevskaya and V.M. Uritzkiy's conclusion about the fractal conjugacy of the human organism and environment [13].

\section{SEASONAL VARIATIONS}

From the general set of fully dated poems from the $19^{\text {th }}-20^{\text {th }}$ centuries we selected and studied 2,551 poems by 132 men and 30 women living in Russia at the time of writing the poetical texts.

While from the $19^{\text {th }}$ century we know over 30 prominent poets and only 4 poetesses, there has been a continuous rise in the number of famous poetesses during the $20^{\text {th }}$ and the $21^{\text {st }}$ centuries. The ratio of poets and poetesses has been gradually shifting towards equal.

Early as while collecting data we have noticed drastic variations in the numbers of poems composed at different seasons by famous poets. It seemed that every poet had had favourite months for writing. The poetry by Alexander Block presents a remarkable example of this phenomenon (see Figure 2 and Table 3).
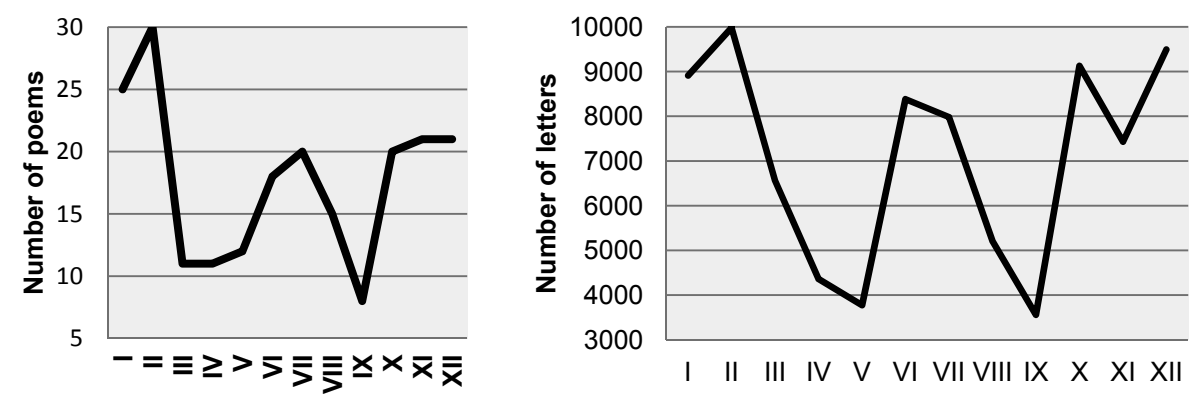

Figure 2. Numbers of poems by A.Block and letters in them at different seasons from 1898 till 1918. 
Table 3. Occurrence of letters in poems by A. Block at different seasons, $\%$

\begin{tabular}{cccccccccccc}
\hline Letter & $\begin{array}{c}\text { Max, } \\
\%\end{array}$ & $\begin{array}{c}\text { Month } \\
\%\end{array}$ & $\begin{array}{c}\text { Min, Month } \\
\%\end{array}$ & $\varphi$ & Letter & $\begin{array}{c}\text { Max, } \\
\%\end{array}$ & Month & $\begin{array}{c}\text { Min, } \\
\%\end{array}$ & Month & $\varphi$ \\
\hline A & 7.75 & XII & 6.67 & I & 2.78 & B & 5.05 & II & 4.22 & VI & 2.6 \\
\hline E & 9.43 & II & 8.05 & VIII & 2.87 & Д & 3.76 & III & 2.97 & XII & 2.68 \\
\hline И & 7.04 & IV & 5.49 & VIII & 3.12 & 3 & 2.43 & I & 1.86 & IX & 1.96 \\
\hline O & 11.02 & VIII & 8.74 & IV & 3.75 & Л & 5.37 & IX & 4.35 & V & 2.01 \\
\hline У & 3.61 & III & 2.58 & II & 3.71 & M & 3.71 & XI & 3.01 & IX & 1.94 \\
\hline b & 2.89 & IV & 2.23 & II & 2.37 & H & 7.63 & I & 6.36 & XI & 3.46 \\
\hline Ю & 1.42 & VIII & 0.73 & IX & 3.08 & P & 4.77 & V & 3.82 & VIII & 2.25 \\
\hline Я & 2.65 & XI & 1.68 & VI & 3.97 & C & 5.99 & V & 4.86 & VIII & 2.36 \\
\hline Б & 2.08 & X & 1.27 & IX & 3.14 & T & 6.95 & VIII & 5.29 & IV & 3.41 \\
\hline
\end{tabular}

Note: Here and in Tables 4 and 5 the significance of difference between maximum and minimum for certain letter calculated by $\varphi$-criterion is, in most cases, at the level of $p \leq 0,001 \div 0,01$.

The obtained data on the numbers of poems and letters in them in correspondence to months and centuries and with the author's gender is shown in Tables 4 and 5 and Figures 3 and 4 . As we can see, number of poets and poems significantly and relevantly varies depending on the month and the year. In the $19^{\text {th }}$ century the number of texts created by poets varied from 70 in March to 131 in August and the number of poems by poetesses changed from 3 in July and October to 10 in February. In the $20^{\text {th }}$ century the number of poems by poets changed from 49 in September to 84 in January and the number of poems by poetesses varied from 13 in April to 29 in March.

As shown in Tables 4 and 5, there are drastic variations in the occurrence of letters, its highest and lowest values, in correspondence to the season and weather conditions.
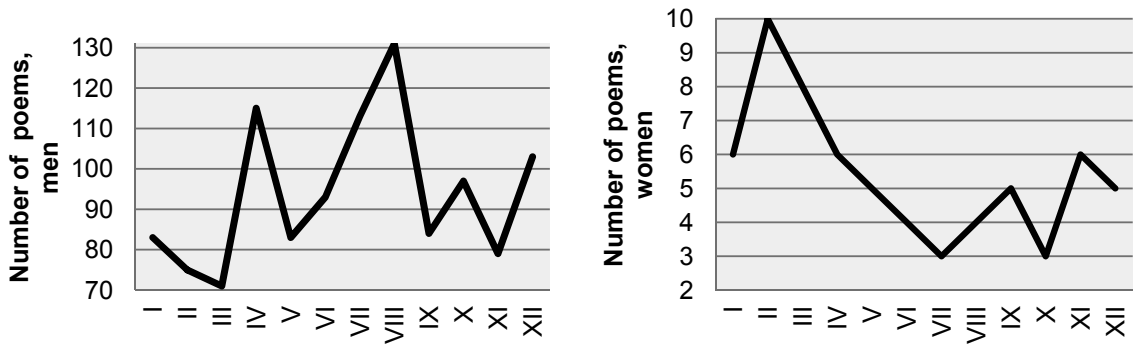

Figure 3. Amount of poems written by poets and poetesses by season, the $19^{\text {th }}$ centuries. 
Table 4. Occurrence of letters in poems by poets and poetesses at different times of year, $\%$, the $19^{\text {th }} \mathrm{C}$.

\begin{tabular}{ccccccccccc}
\hline \multicolumn{1}{c}{ Poets } & \multicolumn{1}{c}{ Poetesses } \\
\hline Letter & Max & Month & Min & Month & $\varphi$ & Max & Month & Min & Month & $\varphi$ \\
\hline A & 7.75 & XII & 6.68 & I & 2.78 & 7.79 & VIII & 5.31 & VI & 2.39 \\
\hline E & 9.43 & II & 8.05 & VIII & 2.87 & 9.62 & V & 7.21 & I & 3.26 \\
\hline И & 7.04 & IV & 5.49 & VIII & 3.12 & 7.35 & VI & 5.68 & I & 2.16 \\
\hline O & 11.03 & VIII & 8.74 & IV & 3.75 & 10.5 & II & 8.24 & VI & 2.37 \\
\hline У & 3.61 & III & 2.58 & II & 3.71 & 4.14 & I & 2.35 & X & 4.46 \\
\hline bI & 2.89 & IV & 2.23 & II & 2.37 & 3.07 & VII & 1.78 & IX & 3.33 \\
\hline Ю & 1.42 & VIII & 0.73 & IX & 3.08 & 1.53 & III & 0.53 & VII & 3.34 \\
\hline Я & 2.65 & XI & 1.68 & VI & 3.97 & 2.72 & IX & 1.85 & VI & 2.00 \\
\hline
\end{tabular}
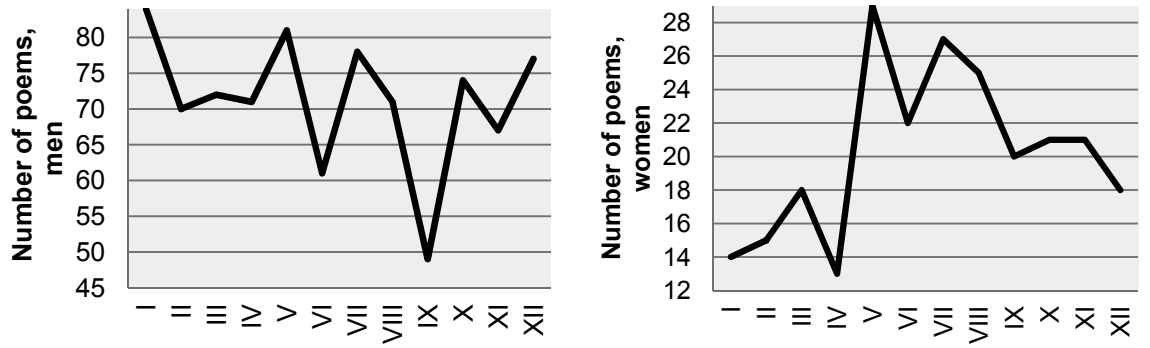

Figure 4. Number of poems by poets and poetesses in correspondence to the season, the $20^{\text {th }}$ century.

The based on the data about A. Block's compositions and generalized data for the $19^{\text {th }}$ and $20^{\text {th }}$ centuries, we are able to conclude the existence of seasonal variations in the poetry created by men and women. There is a combination of influential conditions: temperature, daytime duration, precipitation and humidity, wind, magnetic field, Earth's rotation rate, oxygen level and others.

Differences in seasonal variations for men and women are explained by the differences in their adjustment systems and in their sensitivity to the major seasonal factors - temperature, sun exposure, magnetic fields, cosmic radiation, oxygen level, wind, humidity, etc.

The rising number of poetesses among famous authors from the $19^{\text {th }}$ century till nowadays corresponds, on the one hand, with profound changes in the social parts of men and women in modern society and, on the other hand, with V.A. 
Geodakyan's idea that women take over some men's social functions during prolonged stressful periods [5].

The revealed "preferred" for writing and "ignored" months are a parameter of the individual work style. A possible base for this phenomenon can be the so-called "cosmic imprinting", "prenatal helioimprinting", i.e. the adjustment of the whole adaptive system of an organism to environmental conditions $[8,21]$.

We consider the significant difference between the occurrences of virtually every letter of the alphabet depending on the current year and the month as a manifestation of the adjustment on the speech level. We think that the received results can be used in the field of logopedics.

Table 5. Occurrence of letters in poems by poets and poetesses in different times of year, $\%$, the $20^{\text {th }}$ century.

\begin{tabular}{ccccccccccc}
\hline \multicolumn{1}{c}{ Poets } & \multicolumn{1}{c}{ Poetesses } \\
\hline Letter & Max & Month & Min & Month & $\varphi$ & Max & Month & Min & Month & $\varphi$ \\
\hline A & 7.59 & VI & 6.78 & IX & 3.89 & 8.27 & XI & 7.01 & I & 2.62 \\
\hline Е & 8.92 & III & 8.21 & X & 3.59 & 9.52 & II & 7.96 & XI & 3.04 \\
\hline И & 6.57 & X & 6.0 & II & 3.13 & 6.39 & I & 5.84 & XII & 1.38 \\
\hline O & 10.24 & X & 9.68 & I & 2.72 & 10.46 & I & 9.38 & II & 1.77 \\
\hline У & 3.29 & XI & 2.67 & VII & 4.6 & 3.13 & X & 2.57 & IX & 2.17 \\
\hline Ы & 2.56 & IX & 2.25 & X & 2.97 & 2.47 & II & 1.82 & । & 2.22 \\
\hline Ю & 1.03 & II & 0.79 & I & 1.99 & 1.11 & VI & 0.58 & XI & 3.85 \\
\hline Я & 2.39 & VI & 1.99 & X & 3.69 & 2.23 & II & 1.85 & IV & 1.39 \\
\hline
\end{tabular}

\section{DAILY VARIATIONS}

We selected and analyzed the poems that had an indication of the time of the day whether in the title or in the date of composing. Most of these poems were attributed to nighttime and only a few - to the day and the evening time. The preliminary results reveal the existence of daily variations in letter occurrences in poetical texts, which are gender specific. We will have to continue the study to provide a representative sample and to confirm our conclusion.

As we can see from the presented figures and tables, there are multiyear and seasonal variations in poets' creative activity, which correspond to natural environmental conditions. The temperature index appeared the most influential 
among the studied geocosmic weather indices for 1801-2000, while the solar activity index $\mathrm{W}$ was only the $4^{\text {th }}$ influential. This result confirms accumulating data on global warming in progress.

The information from scientific works and our own research of many years witness the existence of geocosmic conditions and epochs which are favourable or unfavourable for male and female organisms starting from the moment of conception [23]. Apparently, the period the humankind is going through at the moment is an unfavourable one for men. This is why women are becoming more masculine and exchanging social roles with men. It is a natural compensatory reaction of humankind as a complex self-developing system at the transitionary stage.

Thus, phonetic activity and the generation of certain phonemes are influenced bydifferent combinations of weather conditions. The obtained results are confirmed with the conclusions by modern scholars [6, 13, 15, 18, 22, 23]. Particularly, gender specific daily, seasonal and multiyear variations in the parameters of thinking were revealed correlating with several geocosmic factors, as well as the correspondence of musical art with the changes of geocosmic factors [23]. It was shown that redox-reactions in human body depend on geocosmic weather, including Earth's rotation rate [6]. The universal phenomenon of "macroscopic fluctuations" in processes of any origin discovered by S.E. Shnoll and his associates is determined by Earth's motion in heterogeneous and anisotropic space and time [18].

The studies of structural dynamics and the evolution of certain languages usually place the development of phonetic laws in the earliest stage of evolution, where the easiness of pronunciation becomes the major factor [17]. Global changes of natural environment and of climate were the reasons of the evolution of humans [4]. They are also, apparently, the factors in the evolution and development of language. At the present period both sharp changes of climate and rising levels of pollution contribute to the current $40-60 \%$ growth of speech dysfunction in preschoolers [1].

Our study does not engage the importance of social environment which is vital for humans. Social environment obviously impacts the poet's works, judging by long term variations in writings and the poems content. We do not discuss the influence of social environment onto poetical writing in this article due to its limited volume.

In a representative review of studies by Russian and foreign authors V.M. Vladimirskiy [22] demonstrates the correspondence of social processes, including terrorism $[7,22]$, to cosmic weather. It is shown that the birth of prominent 
individuals and the variations in creative activities of artists, writers, composers, physicists and mathematicians are influenced by the solar activity SA and its rhythms. The SA impact onto creative processes is linked to the personality type and the predominant thinking style.

In V.M.Vladimirskiy's opinion, the studies of cosmic weather impact onto sociocultural dynamics attract hardly any attention of the academic community. The researchers who are interested in this topic but belong to specific camps are almost entirely isolated from one another. For instance, the studies of multicentury periods revealed "pulsation of creative writing" [14], which has never been compared with variation of the cosmophysical indices even though they are apparently directly related [22, p. 203, 206].

\section{CONCLUSION}

Poetry is a complex high-level art. It is certainly addressed to educated persons, to attentive readers dearly fond of poems. Nowadays, as A. Kooshner says, "almost everyone, every second person, writes poems. Another question is that there are not - which is the way it is supposed to be - too many good poems. But one still can run into those good ones" [10]. Reviving the habit of regularly reading beautiful poems, matching current environmental conditions, can restore mental health and the vitality of individuals as well as the whole society.

As our findings suggest, there are multiyear, seasonal and daily variations in poetic activity. They correlate to the changes in natural environment and are gender specific. Multiyear variations for the studied period of 1801-2000 appear to be mainly determined, from the highest to the lowest influential, by temperature, Earth's rotation rate, precipitation and solar activity. The attained results correspond to the reports of continuous global warming.

Poetic activity is inseparable from environmental conditions, which poets subconsciously are taking into consideration. It also means that the suggestive potential of speech depends on the current conditions of social and natural environment. Apparently, environmental changes have been, and still are, influencing the evolution of speech and the fractal conjugacy of the human organism and the environment, with the key role belonging to the Earth motion in the inhomogeneous and anisotropic space and time.

Global changes in natural environment and climate changes were the factors in the evolution of humans and, apparently, impact evolution and the development of language. Sharp climate changes of the present time, along with the rising pollution levels, aggravate speech dysfunctions in preschoolers. We think 
that the information about the influence of environmental changes onto composing poems might be used in the practice of speech therapists.

Further research of multiyear and daily variations in poetic creativity, with the attention to gender specifics, is required for formulating solid conclusions.

The author expresses her deep gratitude to N.S. Sidorenkov, Dr.Sci. in Physics and Mathematics, head of Gidromettzentr laboratory, for providing the cosmic weather data, and to Ekaterina Rost for assistance in making this article.

\section{REFERENCES}

1. Arkhipova E.F. (2008). Logopedicheskiy massazh pri dizartrii/ Therapeutic speech massage for dysarthria. Moscow: Astrel Publishing.

2. Chukovskaya L.K. (2000). Pamyati detstva/ In memory of childhood. Vol. 1. Gudyal-Press, 173-328.

3. Danilenko O.I. (1996). Dushevnoe zdorovje i poezia/ Mental health and poetry. St Petersburg: Stroylespechat.

4. Demenokal P. (2014). Potryasennie klimatom/Shaken by Climate. V mire nauki, 11, 18-25.

5. Geodakyan V.A. (1991). Evolutzionnaya teoria pola/ Evolutionary theory of sex. Priroda, 8, 60-69.

6. Gorshkov E.S., Ivanov V.V., Sokolovskiy V.V. (2014). Redoks-reaktzii v kosmobiologii/ Redox-reactions in Cosmobiology. St Petersburg: Polytechnical University Publishing.

7. Grigoryev P.E. (2007). Effekti kosmicheskoy pogodi v terroristicheskoy aktivnosti/ Effects of cosmic weather in terroristic activity. In: Uchenie zapiski Tavricheskogo natzionalnogo universiteta im.V.I. Vernadskogo/ Bulletin of Tavria National University named after V.I. Vernadskiy, 20(1), 28-46.

8. Kaznacheev V.P. (1985). Bioinformatzionnaya funktzia estestvennih elektromagnitnih poley/ Bioinformational function of natural electromagnetic fields. Novosibirsk: Nauka.

9. Kolker A., Ryzhov K. (1970). Kak rozhdaetsia pesnia/ How Songs Are Born. Sovetskaya estrada i tzirk, 7, 18-19.

10. Kooshner A. (2010). Poezia - eto intimnoe delo/ Poetry is an intimate business. An interview given to Lubov Borsulyak. http://www.polit.ru/article/2010/10/28/ kooshner/

11. Krylov A.A. (1998). Ideya tzelostnosti i sistemniy podhod v izuchenii cheloveka/ The idea of wholeness and systemic approach to human studies. Psihologia, $1-35$. 
12. Mayers D. (1999). Sotzialnaya psihologia/ Social Psychology. St Petersburg: Piter.

13. Muzalevskaya N.I. (2000). Analiz ustoychivosti i nadezhnosti bolshih interaktivnyh sistem i ego primenenie v meditzinskoy diagnostike/ Analysis of stability and reliability of large interactive systems and its application in medical diagnostics. Vestnik SbGU, Ser. 4, 2(12), 3-19.

14. Petrov V.M. (2002).. Pul'siruyushchaya intensivnost' literaturnoi zhizni: dinamika russkoi poezii i prozy XVIII-XX vv. Atlas vremennykh variatsii prirodnykh, antropogennykh i sotsial'nykh protsessov. Vol. 3. Yanus-K. Moscow, 587-589.

15. Pobachenko S.V. (2012). Sravnitelnaya otzenka dinamiki pokazateley elektricheskoy aktivnosti mozga $\mathrm{v}$ razlichnih geliofizicheskih usloviyah po dannym kruglosutochnogo monitorin13ga/ Comparative assessment of variations in brain electric activity indices at various heliophysical conditions with data from round-the-clock monitoring. In Sbornik tezisov Mezhdunarodnoy Konferentzii "Vliyanie kosmicheskoy pogody na cheloveka v kosmose I na Zemle". Moscow.

16. Rogozhnikova T.M. Suggestivniy potentzial imeni/ Suggestive potential of personal name. In Teoria i praktika yazikovoy kommunikatzii: Materialy V Mezhdunarodnoy Nauchno-metodicheskoy konferenzii. Ufa, 415-434.

17. Rozhdestvenskiy Yu.V. (1990). Lektzii po obschemu yazikoznaniu/ Lectures on General Linguistics. Moscow: Vysshaya Shkola.

18. Shnoll S.E. (2013). Fraktalnost, “beregovaya linia Vselennoy”, dvizhenie Zemli i "makroskopicheskie fluktuatzii"/ Fractality, "coastline of the Universe", Earth's motion and "macroscopic fluctuations". Biofizica/ Biophysic, 58(2), 357-376.

19. Sidorenkov N.S. (2004). Nestabilnosti vraschenia Zemli/ Irregularities of rotation of the Earth. Vestnik RAN/ The Russian Academy of Sciences Bulletin, 8, 701-709.

20. Sidorenkov N.S. (2012). Geodinamicheskie prichiny dekadnyh izmeneniy klimata/ Geodynamic factors of 10-year climate change cycle. Gidrometeorologicheskie prognozy/ Hydrometeorological forecast, Moscow, 348, 195-214.

21. Trofimov A.V. (2012). Prenatalniy gelioimprinting/ Prenatal Helioimprinting. Novie tehnologii profilakticheskoy meditziny/ New technologies of preventive medicine. Saarbrücken: Palmarium Academic Publishing.

22. Vladimirskiy B.M. (2011). Kosmicheskaya pogoda - klimat i sotzial'nie protzessi/ Cosmic weather - climate and social processes. Izvestia Krimskoy Astrofizicheskoy Observatorii/ The Crimean Astrophysics Observatory review, 107(1), 189-209.

23. Volchek O.D. (2006). Geocosmos i chelovek, monografia/ Geocosmos and Humans: A Monograph. St Petersburg: RSPU Publishing.

24. Volchek O.D. (2014). Adaptive Changes in Speech Perception. Papers on Anthropology, 23(2), 122-134. 
25. Volchek O.D. (2015). Appropriate Sounds and Words in the Light of Ecological Psychology. Papers on Anthropology, 24(2), 129-137.

26. Volchek O.D. (2015). Ekologicheskie aspekti poeticheskogo tvorchestva/ Ecological aspects of poetry writing. In The $7^{\text {th }}$ Russian Conference on ecological psychology. Abstracts. Nestor-Istoria. St Petersburg, 110-112.

27. Zhuravlev A.P. (1974). Foneticheskoe znachenie/ Phonetical meaning. Leningrad: LGU Publishing.

Address for correspondence:

Olga D. Volchek

Saint Petersburg Institute of Humanities

Liflyandskaya str., 4, Saint Peterburg, 190020, Russia

E-mail: volchekod@mail.ru 